\title{
Tissue Engineering Functional Gastrointestinal Regions: The Importance of Stem and Progenitor Cells
}

\author{
Andrew Trecartin and Tracy Grikscheit \\ Department of Pediatric Surgery, Children's Hospital Los Angeles, Los Angeles, California 90027 \\ Correspondence: tgrikscheit@chla.usc.edu
}

\begin{abstract}
The intestine shows extraordinary regenerative potential that might be harnessed to alleviate numerous morbid and lethal human diseases. The intestinal stem cells regenerate the epithelium every 5 days throughout an individual's lifetime. Understanding stem-cell signaling affords power to influence the niche environment for growing intestine. The manifold approaches to tissue engineering may be organized by variations of three basic components required for the transplantation and growth of stem/progenitor cells: (1) cell delivery materials or scaffolds; (2) donor cells including adult stem cells, induced pluripotent stem cells, and in vitro expansion of isolated or cocultured epithelial, smooth muscle, myofibroblasts, or nerve cells; and (3) environmental modulators or biopharmaceuticals. Tissue engineering has been applied to the regeneration of every major region of the gastrointestinal tract from esophagus to colon, with scientists around the world aiming to carry these techniques into human therapy.
\end{abstract}

$T_{\text {is }}^{\mathrm{is}}$ issue engineering the intestine is progressing rapidly owing to advances in stem-cell biology and material science. Originally described in 1994 (Vacanti et al. 1988), the development of tissue-engineered intestine has now been described in both small and large animal models (Grikscheit et al. 2004; Sala et al. 2009; Barthel et al. 2012b; Spurrier and Grikscheit 2013). Tissue-engineered intestine is a promising therapy developed in part as a solution for the devastating consequences of short bowel syndrome (SBS), a condition in which the intestinal length has been severely truncated, affecting the absorption of enteral nutrition. Tissue engineer- ing generally requires transplantation of both a biocompatible scaffold and donor stem/ progenitor cells in an appropriate milieu that will allow for or foster regeneration.

Tissue engineering is dependent on stem/ progenitor cell proliferation and differentiation into all functional cell types, and hence understanding the stem-cell niche is foundational for tissue engineers. The key components of native intestinal tissue including enterocytes, goblet cells, neuroendocrine cells, intestinal stem cells, muscle, and nerve are shown in some versions of tissue-engineered intestine. Tissue-engineered intestine has rescued Lewis rats from

Editor: Joseph P. Vacanti

Additional Perspectives on Tissue Engineering and Regenerative Medicine available at www.perspectivesinmedicine.org

Copyright (C) 2017 Cold Spring Harbor Laboratory Press; all rights reserved; doi: 10.1101/cshperspect.a025700

Cite this article as Cold Spring Harb Perspect Med 2017;7:a025700 
SBS (Grikscheit et al. 2004). Consequently, there is increasing evidence for the functionality of tissue-engineered intestine in addition to histologic evidence for the presence of key cell types.

\section{INTESTINAL STEM AND PROGENITOR CELLS}

Extensive recent investigation into the mechanisms of proliferation and differentiation in the stem-cell niche (Watt and Hogan 2000) confirms that there is rapid and elegant regeneration, and dysregulation leads to malignancy (Krausova and Korinek 2014). Consequently, manipulation of this niche is of interest to tissue engineers. The niche environment centers around the crypt base Lgr5-positive stem cells that divide into both daughter stem cells and transit-amplifying (TA) cells committed to differentiation. Although the direction of these divisions as a population is random, and the number of stem cells remains relatively constant through all divisions, it appears that location in the crypt determines whether a stem cell produces more stem cells or differentiates (Lopez-Garcia et al. 2010; Snippert et al. 2010; Ritsma et al. 2014; Walther and Graham 2014).

The Wnt target gene Lgr5 marks actively proliferating cells at the crypt base with nearly unlimited self-renewal potential (Barker et al. 2007). These Lgr5 cells not only divide into daughter Lgr5 stem cells, but also are the source of TA cells that exit the concentrated niche factors located in the crypt (Barker 2014). The Clevers group showed that Lgr5 RNA is only found in the crypts and is not being transcribed when Wnt is inhibited. These Lgr5 cells were found, by BrdU and Ki67 labeling, to continuously proliferate with an average cycle time of $\sim 24 \mathrm{~h}$. In a reporter mouse, lineage tracing confirmed that Lgr 5 cells proliferated to replace the cells of entire villi in the small intestine and crypts in the colon. Challenges with identifying the low levels of Lgr5 as a marker lead to the discovery of Olfm4-a specific marker for Lgr5positive stem cells that is more highly expressed in the small intestine, but not in other murine gastrointestinal (GI) tissues or bone marrow (Schuijers et al. 2014). Olfm4 is highly expressed in human colon stem cells (Reynolds et al. 2014). Ascl2, a neural notch pathway target, functions in the intestine as a critical Wnt target allowing crypt proliferation (van der Flier et al. 2009).

Lgr5 cells can be cultured to grow into spheres with both crypts and villus structures. Consequently, Lgr 5 cells are not only a critical component of the epithelium, but also may be manipulated to generate large quantities of intestinal epithelium. Enteroids are grown on Matrigel containing laminins and the media requires growth factors epidermal growth factor (EGF), R-spondin 1, and Noggin. With these conditions, they can be continuously split and replated for $>8$ mo (Sato et al. 2009). The addition of sufficient supporting mesenchymal components including muscle, lymphatics, and especially nerve has yet to be solved.

The TA cells at the +4 position are capable of moving down into the crypt to repopulate the stem cells in times of injury (Krausova and Korinek 2014). Insulin-like growth factor 1 (IGF-1) enhances this response to injury (Van Landeghem et al. 2015). When there is no injury, the TA cells normally divide several times as they progress up the crypt and villus until they terminally differentiate. TA cells express Bmil and Tert, although these markers are not limited to the TA cells (Krausova and Korinek 2014). Wdr43 is an additional TA cell marker (Barker et al. 2007). The TA cells' ability to regenerate the crypt may be a valuable asset to future tissue-engineering therapies.

Unlike the enterocytes, the Paneth cells migrate down to the crypt base. Lgr5-positive stem cells give rise to a population of secretory progenitors expressing the ligand Dll1. These Dll1positive cells can regenerate the Lgr5-positive cells in the crypt on damage or provide notch signals to their neighboring TA cells causing differentiation into enterocytes (van Es et al. 2012). A population of Paneth cells, which normally express Dll1 appear capable of losing their Paneth cell identity and regenerating the Lgr5positive stem-cell population after injury (Roth et al. 2012). 


\section{INTESTINAL STEM-CELL SIGNALING}

Wnt- $\beta$-catenin signaling, the canonical Wnt pathway, is critical to survival of the stem-cell niche (Krausova and Korinek 2014). Antagonism leads to death of the crypt and agonism to Lgr5-cell proliferation. Wnt agonists bind to Frizzled-LRP, which then inhibits ubiquitination of $\beta$-catenin, resulting in binding on the effector protein TCF4. Wnt up-regulates expression of several stem-cell markers and its effect is inhibited by axin2. Mutations in the APC gene that inhibit degradation of $\beta$-catenin are implicated in familial adenomatous polyposis and colon cancer. Tissue engineers must maintain conditions that optimize Wnt-based proliferation while balancing the risk of malignant transformation.

Similar to the epidermis, intestinal epithelium secretes Wnt and Wnt inhibitors, which regulate proliferation and differentiation between the crypt and the villus/surface epithelium (van de Wetering et al. 2002; Gregorieff et al. 2005; Lim et al. 2013). The canonical Wnt pathway in the crypt is potentiated by R-spondin acting on Lgr $4 / 5$ receptors to inhibit degradation of $\beta$-catenin and then complex with Tcf- 4 to bind to DNA resulting in transcription (van de Wetering et al. 2002; Gregorieff et al. 2005; Krausova and Korinek 2014). Tcf- 1 appears to inhibit Tcf-4 and Apc, GSK3 $\beta$, and axin are parts of the complex that degrades $\beta$-catenin.

$\mathrm{R}$-spondin causes Paneth cell proliferation and appears to act synergistically and codependently with Wnt to keep enteroids alive. Wnt loss leads to enteroid death within 4 days and R-spondin loss leads to immediate enteroid death (Farin et al. 2012).

A member of the tumor necrosis factor superfamily, TROY, is located with the Lrg5positive cells. Enteroid culture experiments show Troy knockouts can grow with significantly decreased levels of R-spondin compared with wild-type controls, indicating that Troy inhibits R-spondin signaling in intestinal stem cells (Fafilek et al. 2013).

Lgr5 is the marker of the stem cells at the crypt base; however, it appears that Lgr4 and Lgr5 have the same crucial function in the
Wnt pathway because knocking out only Lgr5 has no effect (de Lau et al. 2011). Multiple Wnts and Wnt receptors have regulatory roles in the intestine; however, it appears that Wnt-3, 6, and $9 \mathrm{~b}$ levels correlate with the stem-cell compartment and decrease with distance up the cryptvillus axis (Gregorieff et al. 2005).

One of these Wnt signals in particular, Wnt3, secreted by Paneth cells, is necessary for in vitro intestinal epithelial culture. However, Wnt2b from mesenchymal cells fills the same role (Farin et al. 2012), explaining why Wnt3 knockout in vivo lacks the effect it shows in vitro. Epithelial tissue engineering may benefit from concomitant mesenchymal incorporation or addition of Wnt2b as a biopharmaceutical. Wnt $2 b$ is found in the villus mesenchyme of the small intestine and in what appears to be smooth muscle or endothelial cells of the colon (Gregorieff et al. 2005). Wnt2b likely involves the noncanonical Wnt pathway because it appears in areas that do not have nuclear $\beta$-catenin or the target genes of T-cell factors (TCFs) turned on. The noncanonical Wnt pathway involves varied cellular responses and is less well defined compared with the canonical Wnt pathway (Gregorieff et al. 2005). Intestinal tissue engineering may benefit from an improved understanding of the complex interplay between these overlapping pathways.

Wnt signal alone does not stimulate inner germarial sheath cell (ISC) proliferation. Wnt activation of the phosphatidylinosital-3 kinase (PI3K) and Akt pathway causes intestinal stemcell proliferation, which is normally kept in check by bone morphogenetic protein (BMP) together with phosphatase and tensin homolog (PTEN) (He et al. 2004). BMP inhibits the PI3k-Akt pathway to prevent unlimited cellcycle progression. Smad transcription factors allow the BMP signal to enter the nucleus. Knocking out the BMP pathway allows activation of the PI3k-Akt pathway leading to polyps containing increased numbers of crypts ( $\mathrm{He}$ et al. 2004). Specifically, this BMP inhibition allows more than one stem cell per crypt to accumulate nuclear $\beta$-catenin and crypt fission results. Noggin, a BMP antagonist used extensively for enteroid culture, allows more $\beta$-cate- 
nin to enter the nucleus through the PI3K pathway (He et al. 2004). PTEN inhibits this pathway and, consequently, mutations in PTEN lead to malignancy in multiple organs (Mutter 2001).

Another pathway that interfaces with Wnt signaling is the inflammatory cascade. NF- $к \mathrm{~B}$ enhances the Wnt- $\beta$-catenin pathway, accelerating malignant degeneration (Schwitalla et al. 2013). Consequently, control of the inflammatory response may optimize engineered tissue growth and minimize malignant potential.

The majority of stem-cell niche investigations have been conducted in the small intestine. Paneth cells are an important component as, in addition to antimicrobial secretion, they produce factors necessary for stem-cell maintenance including EGF and Wnt ligands (Sato et al. 2011). Little is known about the source of Wnt in the colon, but a c-kit-positive goblet cell in the colon expresses EGF and notch ligands Dll1 and Dll4 similar to Paneth cells (Farin et al. 2012; Rothenberg et al. 2012; Barker 2014). Consequently, colon tissue engineering may necessitate integration of these Paneth cell equivalents.

An additional marker that appears to be important for epithelial proliferation is Sox9. It is a Wnt target gene and is necessary for both Paneth and stem-cell survival (Blache et al. 2004; Sato et al. 2011). Also, a distinct range of Sox 9 expression is associated with the ability to regenerate the crypt after radiation injury (Van Landeghem et al. 2012).

In addition to Wnt, an understanding of other essential pathways for tissue engineering include notch and Hedgehog ( $\mathrm{Hh}$ ) signaling. The notch ligands Dll1, Dll4, and Jagged, acting on Notch 1 and 2 receptors in the intestine cause expression of Hes1. Hes1 inhibits Math1 thereby regulating intestinal cell differentiation into absorptive enterocytes rather than secretory lineages (Jensen et al. 2000). Dll1 and Dll4 are the notch ligands secreted by Paneth cells (Pellegrinet et al. 2011; Sato et al. 2011).

Loss of any one of the ligands Dll1, Dll4, or Jagged does not affect the stem cells in the crypt. In fact, Jagged loss does not appear to have any effect because simultaneous loss of both Dll1 and Jagged is no different from Dll1 alone-a large increase in goblet cell numbers is seen, but there is no effect on proliferation. Double mutation of both Dll1 and Dll4, however, causes complete intestinal crypt stem-cell loss (Pellegrinet et al. 2011). Consequently, in addition to directing differentiation, Notch signaling is also critical to preventing differentiation in the stem-cell niche.

Hh signaling through factors Sonic Hedgehog (Shh) and Indian Hedgehog (Ihh) is responsible for normal villus formation and its inhibition causes epithelial proliferation (Madison et al. 2005). Ihh restricts Wnt targets to colonic crypts and its loss leads to adenoma formation (van den Brink et al. 2004). Shh and Ihh are limited to the epithelium and appear to provide inhibitory regulation to the Wnt pathway (van den Brink et al. 2004) to form well-developed crypts and villi (Madison et al. 2005; Shyer et al. 2015). Inhibiting Hh causes formation of multibranching villi with structures similar to crypts in their tips. Intestinal subepithelial myofibroblasts (ISEMFs) and smooth muscle cells are also significantly increased in the Hh-inhibited villus tips (Madison et al. 2005). There is evidence that Shh causes increased BMP signals leading to villus formation and loss of stem-cell identity. During intestinal development, the physical shape of the epithelial plane influences the isolation of the stem cells to the crypts and turning a ring of intestine inside out maintains stem cells across the entire epithelium in vitro (Shyer et al. 2015). Accordingly, modulating the geometry of Hh signaling may enable tissue engineers to augment intestinal growth.

As illustrated in the preceding paragraphs, the epithelial signals are under extensive investigation. However, little is understood about the mesenchymal contribution to epithelial proliferation. The mesenchyme surrounding intestinal epithelium may play more vital roles than we recognize. Wnt $2 \mathrm{~b}$ has been addressed previously and another example of a nonepithelial factor is platelet-derived growth factor $\alpha$ (PDGF- $\alpha$ ), a crucial agent in villus formation (Karlsson et al. 2000). Enteric nerves inhabit the mesenchyme in the submucosal and muscular (myenteric) layers. The enteric nervous system (ENS) is implicated in regulating stem-cell prolifera- 
tion, although the exact mechanisms remain largely unknown. Capsaicin initiates an axonal reflex causing cholinergic stimulating increase in thymidine kinase activity and radiolabeled $\left({ }^{3} \mathrm{H}\right)$ thymidine or BrdU incorporation (Lundgren et al. 2011). This capsaicin effect can be blocked by muscarinic and nicotinic receptor blockers. The muscarinic receptors affect the IP3 signaling cascade (Lundgren et al. 2011). Ablation of the myenteric nervous plexus is reported to stimulate crypt-cell proliferation ( $\mathrm{Zu}$ coloto et al. 1997). Therefore, in addition to providing required motility for functional intestine, enteric nerves may alter the stem-cell niche making them an essential component of the tissue engineer's resources.

\section{MATERIALS AND TECHNIQUES}

Both biological materials and bioprosthetics have varying success as scaffolds that provide structure, tissue adherence, stable donor-host cell contact, and biodegradation for engineering tissues. The cellular components of the intestine include categories of epithelium, myofibroblasts, smooth muscle, vasculature, lymphatics, and nerve. These cells must not only be capable of proliferating, but encouraged to do so by the transplanted or supporting material.

When cell integrins contact a surface, ensuing signaling cascades allow the cell to adhere and flatten against the surface. This anchoring stimulates proliferation and spreading (Hersel et al. 2003). Polyglycolic acid (PGA) scaffold has been a workhorse of tissue-engineering experiments and is commercially available in the form of biodegradable sutures. The addition of poly(L-lactic) acid (PLLA) to form a composite has been successful both in vivo and in vitro (Mikos et al. 1993; Grikscheit et al. 2003c). RGD peptides ( $R$, arginine; $G$, glycine; $D$, aspartic acid) promote cell adhesion and ingrowth through integrin binding (Hersel et al. 2003). Both natural and synthetic polymers, including those currently in clinical use such as PGA and PLLA, may be modified to contain RGD surface peptides.

Some approaches implant bare scaffold alone, relying entirely on the surrounding recip- ient tissue's regenerative capacity. However, the results do not support these techniques as practical for engineering whole segments of intestine. Decellularized small intestinal submucosa (SIS) successfully patched intestinal defects in dogs; however, the patch contracted $80 \%$ and full circumferential patches were unsuccessful (Chen and Badylak 2001). The patched area lacked smooth muscle and even epithelial covering may be more a result of contraction rather than true regenerative expansion in subsequent studies (Lee et al. 2008).

Patch grafts of collagen sponge scaffolds show improved overlying small intestinal epithelial regeneration when seeded with stomach smooth muscle cells and, although the graft shrinkage was not quantified and no muscular innervation reported, it shows that cultured muscle cells may offer a valuable adjunct to stimulating epithelial growth (Nakase et al. 2006) A follow-up study did show nerve regeneration in the submucosal layer, but again the patch shrank $70 \%$, posing a problem with stenosis if a tubular intestine was engineered (Nakase et al. 2007). These studies show that scaffolds relying on ingrowth of host tissue to supply the cell types for all intestinal layers will actually shrink and stricture rather than regenerate intestine. Consequently, inoculation of scaffolds with cells that organize into full thickness intestinal tissue is imperative.

In vitro epithelial culture of intestinal organoids or enteroids (Sato et al. 2009) has become a common laboratory technique with potential to produce viable intestinal tissue for scaffold loading. This involves crypt isolation and culture on Matrigel extracted from EngelbrethHolm-Swarm sarcoma (Emonard et al. 1987) with factors EGF, R-spondin, and Noggin. These epithelial cells have proliferated for months, which clearly may translate to in vitro expansion before placement in a tissue-engineered construct (Sato et al. 2009). Colon cells from these cultures have then been successfully engrafted into mouse colon in vivo (Yui et al. 2012). Enteroid culture is also being used to develop models of human intestinal disease (Dekkers et al. 2013; Kovbasnjuk et al. 2013; Wilson et al. 2014). Retrovirus induction may 
be used as an alternative to human patients (Farin et al. 2012). One of the deficits is that enteroids lack any mesenchyme, including sufficient muscle and nerve tissue for functional intestine.

In addition to epithelium, mesenchymal components of intestine such as muscle and nerve have been expanded in isolation. Intestinal smooth muscle was cultured and showed positive markers for neural and glial cells and this was successfully implanted into omentum (Walthers et al. 2014). Isolated smooth muscle culture trades maturity and contractile strength for increased proliferation. However, if intestinal smooth muscle receives exclusively mechanical mincing instead of enzymatic isolation of cells, more nerve elements and contractile strength are preserved (Walthers et al. 2014).

The ENS, a critical component of functional intestine, has reproducibly been expanded from ENS progenitors in vitro (Almond et al. 2007; Bitar and Raghavan 2014). Therefore, ENS progenitors may be propagated as isolated intestinal components, or together with muscle and epithelium for the formation of functional bowel. Cultured enteric nerve tissue also offers a plausible therapy for patients with intestinal dysmotility.

Supplemental compounds may be required to support and enhance growth of tissue-engineered intestine. A currently available biopharmaceutical, Glut-2 (teduglutide), treats human SBS and stimulates in vitro cultured ISEMFs to produce IGF-1 (Leen et al. 2011). ISEMFs appear to be a critical ingredient of engineered intestine because they grow to enclose enteroids implanted in vivo and without them enteroids cannot survive in vivo (Lei et al. 2014). In culture media supplemented with insulin, transferrin, and EGF, enteroids died without R-spondin, but lived with ISEMFs and without exogenous R-spondin. Also, even in culture media with R-spondin, enteroids grew larger and more complex if cocultured with ISEMFs.

Another potential biopharmaceutical is vascular endothelial growth factor (VEGF). VEGF is a known driver of angiogenesis, but additional factors are required for optimal vascular ingrowth. Techniques for sustained delivery of multiple growth factors have been described and shown to improve angiogenesis into a polymer (Richardson et al. 2001). Polymer without growth factors, however, is shown to develop angiogenesis and, interestingly, even the blank polymer in the above study shows signs of vascular growth potential not too far out of range from that containing sustained release of dual growth factors. Limiting the necessary growth factors for tissue engineering will be advantageous for a smooth transition through the Food and Drug Administration (FDA) into clinical therapy. However, tissue-engineered intestine is growth-factor deficient so supplementation may be required (Gardner-Thorpe et al. 2003). Addition of heparin and growth factors such as VEGF and fibroblast growth factor 2 (FGF-2) leads to significantly increased growth into the scaffolds and decreased hypoxia of the cells on the scaffolds (Nillesen et al. 2007; Matthews et al. 2011).

Additional opportunity for biopharmaceutical development lies in Wnt pathway agonism. Short episodes of Wnt exposure are all that is needed for embryonic development and likely this is all that would be needed in tissue engineering as well (Zimmerman et al. 2012). Wnt has a broad range of targets and responses, however, making it undesirable for clinical application in engineering human tissue, but R-spondins have potential to more specifically enhance engineered intestinal growth (Belchior et al. 2014).

Tissue-engineered intestine may not only require supplemental growth factors, but also immune system modulation. Both bioprosthetics and acellular biologics elicit an immune response, posing a challenge to tissue survival on the engineer's scaffold. One approach to attenuating the immune response for acellular esophageal conduits is to use a cross-linking agent such as Genipin (Koch et al. 2012). Copper induces angiogenesis and treatment of biologic scaffolds with copper appears to decrease inflammation while promoting angiogenesis in an esophageal patch model (Tan et al. 2014).

An adjunct technique for engineering intestine is intestinal lengthening by mechanical 
stretching. This distraction enterogenesis results in longer intestine with maintained villus length, smooth muscle hypertrophy, and actually greater crypt depth. The lengthened intestine has been successfully relengthened a single additional time with greater applied mechanical force (Scott et al. 2015).

In addition to cultured intestinal tissue, induced pluripotent stem cells (iPSCs) offer an alternate process for generating intestinal material. Cultured intestinal organoids from pluripotent stem cells show epithelial function and presence of a muscular layer. Growth, in response to massive small bowel resection, was noted in the kidney capsule in an in vivo implant model. There was no evidence presented for an ENS (Watson et al. 2014).

Intestinal epithelium can be generated in vitro from iPSC by exposure to activin-A in the transforming growth factor $\beta$ (TGF- $\beta$ ) superfamily followed by FGF-4 and Wnt3a. These organoids developed villi and proliferative crypts. Paneth cells, enteroendocrine cells, goblet cells, functional enterocytes, and a thin layer of mesenchyme also result. The components for a fully functional intestine including lymphatics and an ENS were lacking (McCracken et al. 2011; Spence et al. 2011).

Initial development of iPSC involves DNA reprogramming via viral infection, nuclear transfer, or cell fusion to express core pluripotency genes. Growth factors have the potential to maintain iPSC in a pluripotent state. The long-term effects of these genetic and epigenetic changes remain to be seen (Hanna et al. 2010).

\section{ESOPHAGUS}

Tissue engineering of the esophagus has been described in multiple reports (Spurrier et al. 2014b; Chian et al. 2015); however, little is known about the esophageal stem cells that make this possible (DeWard et al. 2014). Esophageal organoids can be cultured with exogenous Wnt agonists and the BMP antagonist Noggin, both required for stem-cell self-renewal (DeWard et al. 2014). Consequently, esophageal regeneration relies on endogenous Wnt and BMP signaling. The importance of Wnt signaling in esophageal developmental biology also supports this conclusion (Jacobs et al. 2012).

Activation of the Notch pathway induces differentiation of epithelium and inactivation leads to proliferation, inflammation, and tumor formation in epidermis. In the esophagus, however, Notch inactivation appears to promote proliferation and basal layer crowding, but not tumor formation or inflammation (Alcolea et al. 2014). Not only does Notch inactivation cause sufficient proliferation to regenerate an entire esophageal epithelium, but it also induces proliferation in adjacent cells containing normal Notch signaling (Alcolea et al. 2014). Current literature provides a more precise understanding of stem-cell niche signaling in the small intestine than in the esophagus (Barker et al. 2007; Barker 2014).

Tissue-engineered esophagus applications include esophageal carcinoma and congenital atresia. Current therapies for esophageal replacement include gastric pull-up and jejunal or colonic interposition (Holland et al. 2009). There are major associated complications including delayed gastric emptying, conduit necrosis, stricture, fibrosis, reflux, and dysmotility with recurrent aspiration (Holland et al. 2009; Chen 2014; Meyerson and Mehta 2014). Jejunal interposition is an extensive procedure often requiring microsurgery (Gaur and Blackmon 2014) and colonic interposition can be complicated by colonic lengthening (Holland et al. 2009).

The esophagus is comprised of a proliferative basal layer supporting multiple strata of keratinocytes (Doupe et al. 2012). These proliferative cells previously appeared to be a uniform population capable of homeostasis, repair, and return to homeostasis after injury. There initially appeared to be no unique rapid or slow cycling cells within this population based on clonal labeling (Doupe et al. 2012). Further studies, however, suggest the presence of certain basal cell populations that provide self-renewal and regeneration along with other populations more directly leading to differentiation (Potten and Loeffler 1990; DeWard et al. 2014).

The basal cell layer appears to be the primary source of Sox 2 expression implicated in de- 
velopment of squamous cell carcinoma of the esophagus (Liu et al. 2013). The esophagus and trachea initially develop from a single tube and Sox 2 heterozygocity is associated with tracheoesophageal fistula. Embryonal expression of Sox 2 appears to cause development of the esophagus in contrast to $\mathrm{Nkx2.1}$, leading to tracheal development (Que et al. 2007; Jacobs et al. 2012). The niche environment regulating these populations of proliferating epithelial cells, however, has not yet been described in the esophagus (DeWard et al. 2014). However, these stem cells are likely the only group regenerating the esophagus because bone marrow-derived cells do not incorporate into esophageal epithelium (Nieponice et al. 2013).

Esophageal engineering has been described using a variety of methods. However, it remains challenging to replace long segments of full thickness esophagus. Early reports with a fully synthetic esophageal replacement-Dacroncovered Phycon-showed survival in the animal model, but the graft extruded in the majority of survivors (Fukushima et al. 1983). All esophageal layers were present only next to the anastomoses leaving a long middle segment with simply a thin layer of squamous epithelium over fibrous tissue (Chen and Beierle 2004).

Human esophageal epithelial cells have been grown in vivo directly on muscle and on scaffold wrapped in muscle (Sato et al. 1993, 1994). The addition of human fibroblasts improved epithelial stratification, but there was still no evidence of muscle or nerve (Miki et al. 1999). Scaffold loaded with oral epithelial cells has been described for esophageal regeneration after subucosal dissection, but this is limited to epithelium only and not full thickness esophagus (Ohki et al. 2012).

Reconstruction of $5 \mathrm{~cm}$ segments of esophagus has been reported in dogs using porcine extracellular bladder matrix. Successful regeneration was limited to the epithelium, submucosa, and required at least a partial native esophageal muscular layer without which strictures developed (Badylak et al. 2005). Another report describes PGA scaffolds loaded with oral keratinocytes and fibroblasts successfully transplanted into a canine esophageal resection
(Nakase et al. 2008). However, this segment remained aperistaltic.

A $1.5 \mathrm{~cm}$ tubular decellularized esophageal graft seeded with mesenchymal stem cells maintained patency in the rat model. Epithelium, nerve, and muscle were identified in the graft. No original donor cells were identified suggesting ingrowth of adjacent cells (Sjoqvist et al. 2014).

Badylak and colleagues describes use of an extracellular matrix scaffold of porcine bladder as an esophageal patch in four human patients (Nieponice et al. 2014). However, this was in the context of a focal defect rather than a circumferential esophageal interposition. Generation of full thickness esophagus from both murine and human tissue, complete with the critical components for function-regenerating epithelium, smooth muscle, and an ENS-has been reported more recently (Spurrier et al. 2014b). This report includes evidence that the esophageal organoid units, which are transplanted to form the engineered esophagus can be maintained in culture and also preserved after vitrification. An esophageal interposition graft using this technique has been described previously in Lewis rats. Tissue-engineered esophagus was even generated from some adult donors (Grikscheit et al. 2003a). The next challenge will be generating larger quantities of esophagus from minimal transplanted tissue.

\section{STOMACH}

Gastric cancer is one of the most common malignancies in the world and its treatment requires resection leaving many patients susceptible to postgastrectomy syndrome, reflux esophagitis, protein calorie malnutrition, vitamin B12, and iron deficiency (Maemura et al. 2013). Gastric epithelial structure consists of pits with glands and at their junction, the isthmus, lies a proliferative population giving rise to the four major cell types: mucous cells, enteroendocrine cells, zymogen/chief, and parietal cells (Bjerknes and Cheng 2002). Clevers group identified a population of Lgr5-positive stem cells in the adult pylorus that are able to form gastric organoids in vitro from a single cell (Bar- 
ker et al. 2010). These Lgr5-positive cells repopulate the gland and give rise to the major cell types of mucous cells, enteroendocrine cells, parietal cells, and gastrin-secreting cells in the pylorus.

In the body of the adult stomach, a different stem cell, the Troy-positive chief cell at the base of the gland, is able to give rise to the major epithelial lineages (Stange et al. 2013). Again, these Troy-positive chief cells are able to form gastric organoids from single cells. Interestingly, the Troy-positive cells show characteristics of mature chief or parietal cells with their expression of either gastric intrinsic factor or the $\mathrm{H}^{+} /$ $\mathrm{K}^{+} /$ATPase, and electron microscopy reveals zymogen granules or nuclear and cytoplasmic structures of parietal cells. The primary proliferative zone is the isthmus, but its ablation stimulates division of the Troy-positive cells in the base of the gland (Stange et al. 2013).

Growth and maintenance of the stem cells at the base of the gland are dependent on Wnt signaling. Withdrawal of Wnt and R-spondin causes gastric organoid cultures to differentiate away from expression of stem-cell markers into mature gastric pit cells (Bartfeld et al. 2015). Unlike intestinal culture, long-term gastric organoid culture required TGF- $\beta$ inhibitor to be added to the growth factors. These organoids were also able to show infection with Helicobacter pylori (Bartfeld et al. 2015). Embryonic development of gastric tissue is dependent on expression of the Barxl gene leading to Wnt antagonism although the implication for postnatal tissue is unclear (Kim et al. 2005).

Many techniques have been used to attempt engineering of gastric tissue. A scaffold consisting of a porcine collagen matrix on polyglycolic acid patched a gastric defect in dogs together with a layer of protecting silicone. Although parietal cell function appeared to be present, the muscular contraction of the wall was absent (Hori et al. 2001, 2002). Mucosal regeneration over a three-layer biodegradable sheet repaired a canine gastric defect; however, no muscular layer spanned the defect that subsequently contracted 60\%-80\% (Araki et al. 2009). SIS has also been used as a gastric patch. Coculture with mesenchymal stem cells improved growth of the smooth muscle layer. Interestingly, however, SIS alone produced similar functional outcomes when contractility was tested, suggesting that ingrowth of muscle and nerve is crucial to patch success, posing a limitation to generation of large quantities of gastric tissue (Nakatsu et al. 2013).

Vacanti's group first described generation of tissue-engineered stomach (TES) in a rat model with organoid units containing components of all stomach layers (Grikscheit et al. 2003b). TES mucosa contains parietal cells, gastrin-producing $\mathrm{G}$ cells, and mucous cells. A smooth muscle layer was present next to the mucosa. TES was connected after total gastrectomy in rats and showed significant improvement in anemia compared with controls without gastrectomy (Maemura et al. 2008, 2013).

TES has also been reported in the mouse model (Speer et al. 2011) and in a preclinical large animal model (Sala et al. 2009). Six-weekold Yorkshire swine successfully received autologous implantation of TES that grew gastric epithelium containing goblet cells surrounded by a smooth muscle layer (Sala et al. 2009).

\section{SMALL INTESTINE}

Tissue-engineered small intestine (TESI) is made possible by the regenerative potential of the stem-cell niche, now better understood than when the first TESI was described. The clinical utility of TESI is clear with SBS's morbid course leading to a $10 \%-40 \%$ mortality depending on the definition and follow-up (Wales et al. 2005; Demehri et al. 2015). Patients waiting for intestinal transplant have a mortality of $\sim 16 \%$ per year and, if received, the 5-year graft survival is $<40 \%$. Approximately $40 \%$ of all transplant recipients have died within 5 years (Garg et al. 2011).

Early successful growth of TESI in Lewis rats revealed a mucosa-containing goblet cells, Paneth cells, crypts containing proliferating cells, and a surrounding smooth muscle layer (Choi and Vacanti 1997). TESI contained crypts and villi similar to native intestine. The brush border was positive for the enzyme sucrase and evidence for ion transport activity was present 
although reduced compared with native intestine (Choi et al. 1998). The intestinal immune tissue in TESI more closely resembled that of native jejunum when matured in continuity with native intestine thus showing ability to respond to luminal factors (Perez et al. 2002). Anastomosis also stimulates significant proliferation and expansion of crypts, villi, muscle, and SGLT1 expression

Not only is TESI structurally similar to native intestine, but it has also been successfully anastomosed to native intestine (Kaihara et al. 1999, 2000). Treatment with GLP-2, currently in clinical trials as Teduglutide, stimulated increased proliferation and decreased apoptosis in TESI. GLP-2 action on TESI resulted in increased villus height, crypt depth, and transporter SGLT1 expression (Ramsanahie et al. 2003). In addition to the intestinal adaptation experiments with GLP-2, FGF-10 overexpression was found to improve TESI growth significantly (Torashima et al. 2013).

TESI function was shown in Lewis rats, which can better tolerate serial survival surgery. Lewis rats were rescued from SBS. Following $80 \%$ small bowel resection, rats with TESI interposition showed significantly improved weight gain compared with resection alone. Vitamin B12 levels were also significantly higher in the TESI group (Grikscheit et al. 2004).

Later, the TESI model was transitioned to a mouse host providing the advantage of investigating the mechanism via various transgenic strains (Chen et al. 2006; Sala et al. 2011). Murine TESI formed structurally similar to native small intestine and contained the same differentiated Paneth, goblet, enteroendocrine, and enterocyte cells. In an early report of a large animal model, 6-week-old Yorkshire swine hosted TESI structurally similar to native intestine containing neurofilaments, muscle, proliferative stem-cell compartment crypts surrounded by ISEMFs, goblet cells, enteroendocrine cells, and villi (Sala et al. 2009).

Implantation of actin-GFP organoid units showed that the entire TESI epithelium was of donor origin, whereas the supporting mesenchyme was a combination of both donor and host tissue. Even some vasculature was found to be of donor origin in addition to ingrowth of donor vessels. TESI contained Lgr5-positive cells in the base of the crypts with adjacent ISEMFs as in native intestine. Donor ganglion cells were found in the smooth muscle layer. Donor cells in TESI were proliferating as confirmed by increased GFP-positive cells at successive time points up to 6 weeks (Sala et al. 2011). Submucosa and villus lymphatics develop spontaneously in TESI, enabling absorption and transport of luminal fatty acids (Duxbury et al. 2004). Presence of nerve and lymphatics further establish TESI's functional capacity for motility and absorption.

The technique for generation of TESI involves mechanical mincing of the tissue followed by enzymatic digestion before loading onto a PLLA coated nonwoven PGA scaffold. The loaded scaffolds are then wrapped in the omentum of the host (Barthel et al. 2012b). In comparison with native intestine of similar age, TESI is deficient in VEGF and FGF-2, suggesting a benefit to the addition of biopharmaceuticals (Gardner-Thorpe et al. 2003).

VEGF overexpression leads to increased growth of TESI both macroscopically and with increased crypt/villus depth/height (Matthews et al. 2011). TESI was generated from transgenic mice and VEGF expression induced after implantation. A marked increase in vasculature and proliferative cells in TESI resulted.

Finally, postnatal human TESI was first reported in 2013 (Levin et al. 2013). Human TESI in a NOD-SCID host grew crypt and villus structures confirmed to be of human origin by $\beta 2$ microglobulin. Adjacent to the epithelium were ISEMFs and a smooth muscle layer. Subepithelial glia similar to Meissner's plexus in native intestine were noted in tissue-engineered intestine. The enterocytes lining the villi showed positive villin staining of the brush border. Goblet cells, Paneth cells, and enteroendocrine cells were also noted in human TESI (Levin et al. 2013).

The next step in preparation for clinical trials will be to generate extensive quantities of TESI in a large animal model. Translational barriers to be overcome include multiplying the mesenchyme-containing muscle and nerve 
along with the proliferation of the epithelium already shown by Clevers.

The challenge remains of implanting tissue when host factors are optimized. Often at the time of surgery, autologous implantation would be subject to failure because of infection, inflammation, malnutrition, and other physiologic stresses.

Culture techniques offer the potential to expand intestinal epithelium in vitro (Sato et al. 2009). Pluripotent stem cells have been developed into many of the components of functional intestine, although development of an innervated smooth muscle layer is missing and immunosuppression would be required (Watson et al. 2014).

Vitrification offers the potential to cryopreserve donor tissue until physiologic conditions are optimal for autologous implantation. Spurrier et al. (2014b) described a vitrification protocol involving suspension of organoid units in increasing concentrations of dimethyl sulfoxide (DMSO) followed by cooling in an ethanol bath to $-13^{\circ} \mathrm{C}$, slow cooling to $-80^{\circ} \mathrm{C}$, and then storage in liquid nitrogen. Combined with rapid thawing, this technique significantly increased the viability of preserved cells.

\section{COLON}

The colon functions as a reservoir that hosts beneficial microbes producing short-chain fatty acids, and reabsorbs water and electrolytes (Sandle 1998). Colon is damaged or lost in a variety of disease processes (Burisch and Munkholm 2013; Hukkinen et al. 2014) and the therapeutic options for reconstruction have complications that highlight the loss of colonic absorptive function and may be prone to inflammation (Hahnloser et al. 2007).

The colon lacks Paneth cells and the sources of Notch factor Dll come from CD117-positive goblet cells, whereas the Wnt may come from fibroblasts (Krausova and Korinek 2014). The Clevers group found that colon epithelial culture is completely dependent on Wnt-enriched media, meaning that in vivo colonic stem cells require Wnt from mesenchymal sources (Farin et al. 2012). Contrasting to the critical ingredi- ents for small intestine organoid culture of EGF, R-spondin, and Noggin, colonic organoid culture required Wnt3a instead of or in addition to R-spondin (Yui et al. 2012). Bovine serum albumin (BSA) was required, and Noggin, EGF, and hepatocyte growth factor (HGF) were dispensable, but augmented colonic crypt growth.

Using an inducible Lgr5-EGFP strain, the Clevers group showed that colonic crypt growth in vitro could be sustained from a single Lgr5positive progenitor cell. Cultured crypt organoids were introduced into the lumen of dextran sodium sulfate (DSS)-induced colitis and were found to incorporate into the host epithelium (Yui et al. 2012).

Lgr5 and Sox 9 both appear to be elevated in the colonic stem cells and single Sox $9^{\text {high }}$ cells have also been shown to develop colonic organoids in culture (Ramalingam et al. 2012). Coculture with myofibroblasts has been shown to improve colonocyte growth (Hirokawa et al. 2014). Similar to BMP suppression of the Wnt pathway, the TGF- $\beta$ suppression of Wnt inhibits colonic crypt proliferation, whereas TGF- $\beta$ inhibition with A83-01 stimulates growth (Reynolds et al. 2014).

Advances in manipulation of colon stemcell biology will continue to improve production of tissue-engineered colon (TEC), although its first description predated much of this work (Grikscheit et al. 2003c). In 2003, consistent TEC production was described from neonatal, adult, and from TEC donor tissue itself in Lewis rats (Grikscheit et al. 2003c). Histology showed mature crypts with neuroendocrine cells, goblet cells, apical microvilli, tight junctions, submucosa, a longitudinal smooth muscle layer, and ganglia. All 30 rats generated TEC with a mucosal lumen and basement membrane.

Nonwoven PGA coated in PLLA and implanted in the omentum supported optimal growth of TEC cysts with a continuous lumen. Alternate conditions induced formation of multiple smaller cysts. TEC was also successfully anastomosed to small intestine and colon. Using chamber studies showed intact ion transport across TEC denoting a functional mucosa (Grikscheit et al. 2003c). 
Direct applicability of TEC to clinical practice was shown by comparing ileostomy alone to ileostomy with a TEC pouch in a rat model (Grikscheit et al. 2002). A striking outcome of decreased weight loss in the TEC pouch group was likely caused by multiple effects caused by the TEC. Stool output in the TEC group had a significantly lower water content and greater short-chain fatty acid concentration than stool from ileostomy alone. Higher serum levels of total bile acids suggested improved bile acid reabsorption in the TEC pouch group. No evidence of inflammation was found in the TEC pouch, a key clinical implication in light of the risk of pouchitis with any small intestinal reservoir (Grikscheit et al. 2002).

Transitioning from production of rodent TEC, Barthel and colleagues reported growth of human tissue-engineered colon (hTEC). Proliferating human colon with luminal structures similar to native colon was noted. Enteroendocrine cells, mucin-producing goblet cells, and a surrounding muscular layer with neural markers were all present in hTEC (Barthel et al. 2012a). Additional successes in showing colonic function in large animal models are necessary before transitioning to human therapy.

One of the barriers to colonic function in both common congenital dysmotility, such as Hirschprung's disease, and in engineering the patient's tissue is development of a functional ENS (Heanue and Pachnis 2007). Autologous ENS stem cells show promise for clinical therapeutic use (El-Nachef and Grikscheit 2014). Multiple reports show successful transplantation of ENS cells into aganglionic colon; however, incorporation into aganglionic hTEC in vivo has yet to be achieved (Metzger et al. 2009; Bitar and Raghavan 2014).

\section{CONCLUSION}

Tissue engineering of the GI tract has advanced greatly in the past two decades toward translation to clinical practice. The need remains for definitive treatment of conditions such as SBS. The groundwork has been laid to work toward generation of significant amounts of functional GI tissue in large animal models to clarify the requirements for human trials. Further progress will require scientists and clinicians to advance the field through collaboration.

\section{REFERENCES}

Alcolea MP, Greulich P, Wabik A, Frede J, Simons BD, Jones PH. 2014. Differentiation imbalance in single oesophageal progenitor cells causes clonal immortalization and field change. Nat Cell Biol 16: 615-622.

Almond S, Lindley RM, Kenny SE, Connell MG, Edgar DH. 2007. Characterisation and transplantation of enteric nervous system progenitor cells. Gut 5: 489-496.

Araki M, Tao H, Sato T, Nakajima N, Hyon SH, Nagayasu T, Nakamura T. 2009. Development of a new tissue-engineered sheet for reconstruction of the stomach. Artif Organs 33: 818-826.

Badylak SF, Vorp DA, Spievack AR, Simmons-Byrd A, Hanke J, Freytes DO, Thapa A, Gilbert TW, Nieponice A. 2005. Esophageal reconstruction with ECM and muscle tissue in a dog model. J Surg Res 128: 87-97.

Barker N. 2014. Adult intestinal stem cells: Critical drivers of epithelial homeostasis and regeneration. Nat Rev Mol Cell Biol 15: 19-33.

Barker N, van Es JH, Kuipers J, Kujala P, van den Born M, Cozijnsen M, Haegebarth A, Korving J, Begthel H, Peters PJ, et al. 2007. Identification of stem cells in small intestine and colon by marker gene Lgr5. Nature 449: 10031007.

Barker N, Huch M, Kujala P, van de Wetering M, Snippert $\mathrm{HJ}$, van Es JH, Sato T, Stange DE, Begthel H, van den Born M, et al. 2010. Lgr $5^{+ \text {ve }}$ stem cells drive self-renewal in the stomach and build long-lived gastric units in vitro. Cell Stem Cell 6: 25-36.

Bartfeld S, Bayram T, van de Wetering M, Huch M, Begthel H, Kujala P, Vries R, Peters PJ, Clevers H. 2015. In vitro expansion of human gastric epithelial stem cells and their responses to bacterial infection. Gastroenterology 148: 126-136.e6.

Barthel ER, Levin DE, Speer AL, Sala FG, Torashima Y, Hou X, Grikscheit TC. 2012a. Human tissue-engineered colon forms from postnatal progenitor cells: An in vivo murine model. Regen Med 7: 807-818.

Barthel ER, Speer AL, Levin DE, Sala FG, Hou X, Torashima Y, Wigfall CM, Grikscheit TC. 2012b. Tissue engineering of the intestine in a murine model. J Vis Exp 70: e4279.

Belchior GG, Sogayar MC, Grikscheit TC. 2014. Stem cells and biopharmaceuticals: Vital roles in the growth of tissue-engineered small intestine. Semin Pediatr Surg 23: 141-149.

Bitar KN, Raghavan S. 2014. Stem cell therapy for GI neuromuscular disorders. Curr Gastroenterol Rep 16: 419.

Bjerknes M, Cheng H. 2002. Multipotential stem cells in adult mouse gastric epithelium. Am J Physiol Gastrointest Liver Physiol 283: G767-G777.

Blache P, van de Wetering M, Duluc I, Domon C, Berta P, Freund JN, Clevers H, Jay P. 2004. SOX9 is an intestine crypt transcription factor, is regulated by the Wnt pathway, and represses the CDX2 and MUC2 genes. J Cell Biol 166: $37-47$. 
Burisch J, Munkholm P. 2013. Inflammatory bowel disease epidemiology. Curr Opin Gastroenterol 29: 357-362.

Chen KN. 2014. Managing complications I: Leaks, strictures, emptying, reflux, chylothorax. J Thorac Dis 6: S355-S363.

Chen MK, Badylak SF. 2001. Small bowel tissue engineering using small intestinal submucosa as a scaffold. J Surg Res 99: $352-358$.

Chen MK, Beierle EA. 2004. Animal models for intestinal tissue engineering. Biomaterials 25: 1675-1681.

Chen DC, Agopian VG, Avansino JR, Lee JK, Farley SM, Stelzner M. 2006. Optical tissue window: A novel model for optimizing engraftment of intestinal stem cell organoids. J Surg Res 134: 52-60.

Chian KS, Leong MF, Kono K. 2015. Regenerative medicine for oesophageal reconstruction after cancer treatment. Lancet Oncol 16: e84-e92.

Choi RS, Vacanti JP. 1997. Preliminary studies of tissue-engineered intestine using isolated epithelial organoid units on tubular synthetic biodegradable scaffolds. Transplant Proc 29: 848-851.

Choi RS, Riegler M, Pothoulakis C, Kim BS, Mooney D, Vacanti M, Vacanti JP. 1998. Studies of brush border enzymes, basement membrane components, and electrophysiology of tissue-engineered neointestine. J Pediatr Surg 33: 991-996.

Dekkers JF, Wiegerinck CL, de Jonge HR, Bronsveld I, Janssens HM, de Winter-de Groot KM, Brandsma AM, de Jong NW, Bijvelds MJ, Scholte BJ, et al. 2013. A functional CFTR assay using primary cystic fibrosis intestinal organoids. Nat Med 19: 939-945.

de Lau W, Barker N, Low TY, Koo BK, Li VS, Teunissen H, Kujala P, Haegebarth A, Peters PJ, van de Wetering M, et al. 2011. Lgr5 homologues associate with Wnt receptors and mediate R-spondin signalling. Nature 476: 293-297.

Demehri FR, Stephens L, Herrman E, West B, Mehringer A, Arnold MA, Brown PI, Teitelbaum DH. 2015. Enteral autonomy in pediatric short bowel syndrome: Predictive factors one year after diagnosis. J Pediatr Surg 50: 131135.

DeWard AD, Cramer J, Lagasse E. 2014. Cellular heterogeneity in the mouse esophagus implicates the presence of a nonquiescent epithelial stem cell population. Cell Rep 9: 701-711.

Doupe DP, Alcolea MP, Roshan A, Zhang G, Klein AM, Simons BD, Jones PH. 2012. A single progenitor population switches behavior to maintain and repair esophageal epithelium. Science 337: 1091-1093.

Duxbury MS, Grikscheit TC, Gardner-Thorpe J, Rocha FG, Ito H, Perez A, Ashley SW, Vacanti JP, Whang EE. 2004. Lymphangiogenesis in tissue-engineered small intestine. Transplantation 77: 1162-1166.

El-Nachef W, Grikscheit T. 2014. Enteric nervous system cell replacement therapy for Hirschsprung disease: Beyond tissue-engineered intestine. Eur J Pediatr Surg 24: $214-$ 218.

Emonard H, Grimaud JA, Nusgens B, Lapiere CM, Foidart JM. 1987. Reconstituted basement-membrane matrix modulates fibroblast activities in vitro. J Cell Physiol 133: $95-102$.
Fafilek B, Krausova M, Vojtechova M, Pospichalova V, Tumova L, Sloncova E, Huranova M, Stancikova J, Hlavata A, Svec J, et al. 2013. Troy, a tumor necrosis factor receptor family member, interacts with lgr5 to inhibit Wnt signaling in intestinal stem cells. Gastroenterology 144: 381-391.

Farin HF, Van Es JH, Clevers H. 2012. Redundant sources of Wnt regulate intestinal stem cells and promote formation of Paneth cells. Gastroenterology 143: 1518-1529.e7.

Fukushima M, Kako N, Chiba K, Kawaguchi T, Kimura Y, Sato M, Yamauchi M, Koie H. 1983. Seven-year follow-up study after the replacement of the esophagus with an artificial esophagus in the dog. Surgery 93: 70-77.

Gardner-Thorpe J, Grikscheit TC, Ito H, Perez A, Ashley SW, Vacanti JP, Whang EE. 2003. Angiogenesis in tissue-engineered small intestine. Tissue Eng 9: 1255-1261.

Garg M, Jones RM, Vaughan RB, Testro AG. 2011. Intestinal transplantation: Current status and future directions. $J$ Gastroenterol Hepatol 26: 1221-1228.

Gaur P, Blackmon SH. 2014. Jejunal graft conduits after esophagectomy. J Thorac Dis 6: S333-S340.

Gregorieff A, Pinto D, Begthel H, Destree O, Kielman M, Clevers H. 2005. Expression pattern of Wnt signaling components in the adult intestine. Gastroenterology 129: $626-638$.

Grikscheit TC, Ogilvie JB, Ochoa ER, Alsberg E, Mooney D, Vacanti JP. 2002. Tissue-engineered colon exhibits function in vivo. Surgery 132: 200-204.

Grikscheit T, Ochoa ER, Srinivasan A, Gaissert H, Vacanti JP. 2003a. Tissue-engineered esophagus: Experimental substitution by onlay patch or interposition. $J$ Thorac Cardiovasc Surg 126: 537-544.

Grikscheit T, Srinivasan A, Vacanti JP. 2003b. Tissue-engineered stomach: A preliminary report of a versatile in vivo model with therapeutic potential. J Pediatr Surg 38: $1305-1309$.

Grikscheit TC, Ochoa ER, Ramsanahie A, Alsberg E, Mooney D, Whang EE, Vacanti JP. 2003c. Tissue-engineered large intestine resembles native colon with appropriate in vitro physiology and architecture. Ann Surg 238: $35-41$.

Grikscheit TC, Siddique A, Ochoa ER, Srinivasan A, Alsberg E, Hodin RA, Vacanti JP. 2004. Tissue-engineered small intestine improves recovery after massive small bowel resection. Ann Surg 240: 748-754.

Hahnloser D, Pemberton JH, Wolff BG, Larson DR, Crownhart BS, Dozois RR. 2007. Results at up to 20 years after ileal pouch-anal anastomosis for chronic ulcerative colitis. Br J Surg 94: 333-340.

Hanna JH, Saha K, Jaenisch R. 2010. Pluripotency and cellular reprogramming: Facts, hypotheses, unresolved issues. Cell 143: 508-525.

He XC, Zhang J, Tong WG, Tawfik O, Ross J, Scoville DH, Tian Q, Zeng X, He X, Wiedemann LM, et al. 2004. BMP signaling inhibits intestinal stem cell self-renewal through suppression of Wnt- $\beta$-catenin signaling. Nat Genet 36: 1117-1121.

Heanue TA, Pachnis V. 2007. Enteric nervous system development and Hirschsprung's disease: Advances in genetic and stem cell studies. Nat Rev Neurosci 8: 466-479. 
Hersel U, Dahmen C, Kessler H. 2003. RGD modified polymers: Biomaterials for stimulated cell adhesion and beyond. Biomaterials 24: 4385-4415.

Hirokawa Y, Yip KH, Tan CW, Burgess AW. 2014. Colonic myofibroblast cell line stimulates colonoid formation. Am J Physiol Gastrointest Liver Physiol 306: G547-G556.

Holland AJ, Ron O, Pierro A, Drake D, Curry JI, Kiely EM Spitz L. 2009. Surgical outcomes of esophageal atresia without fistula for 24 years at a single institution. J Pediatr Surg 44: 1928-1932.

Hori Y, Nakamura T, Matsumoto K, Kurokawa Y, Satomi S, Shimizu Y. 2001. Experimental study on in situ tissue engineering of the stomach by an acellular collagen sponge scaffold graft. ASAIO J 47: 206-210.

Hori Y, Nakamura T, Kimura D, Kaino K, Kurokawa Y, Satomi S, Shimizu Y. 2002. Functional analysis of the tissueengineered stomach wall. Artif Organs 26: 868-872.

Hukkinen M, Koivusalo A, Rintala RJ, Pakarinen MP. 2014. Restorative proctocolectomy with J-pouch ileoanal anastomosis for total colonic aganglionosis among neonates and infants. J Pediatr Surg 49: 570-574.

Jacobs IJ, Ku WY, Que J. 2012. Genetic and cellular mechanisms regulating anterior foregut and esophageal development. Dev Biol 369: 54-64.

Jensen J, Pedersen EE, Galante P, Hald J, Heller RS, Ishibashi M, Kageyama R, Guillemot F, Serup P, Madsen OD. 2000. Control of endodermal endocrine development by Hes1. Nat Genet 24: 36-44.

Kaihara S, Kim SS, Benvenuto M, Choi R, Kim BS, Mooney D, Tanaka K, Vacanti JP. 1999. Anastomosis between tissue-engineered intestine and native small bowel. Transplant Proc 31: 661-662.

Kaihara S, Kim SS, Kim BS, Mooney D, Tanaka K, Vacanti JP. 2000. Long-term follow-up of tissue-engineered intestine after anastomosis to native small bowel. Transplantation 69: 1927-1932.

Karlsson L, Lindahl P, Heath JK, Betsholtz C. 2000. Abnormal gastrointestinal development in PDGF-A and PDGFR- $\alpha$ deficient mice implicates a novel mesenchymal structure with putative instructive properties in villus morphogenesis. Development 127: 3457-3466.

Kim BM, Buchner G, Miletich I, Sharpe PT, Shivdasani RA. 2005. The stomach mesenchymal transcription factor Barx1 specifies gastric epithelial identity through inhibition of transient Wnt signaling. Dev Cell 8: 611-622.

Koch H, Graneist C, Emmrich F, Till H, Metzger R, Aupperle H, Schierle K, Sack U, Boldt A. 2012. Xenogenic esophagus scaffolds fixed with several agents: Comparative in vivo study of rejection and inflammation. J Biomed Biotechnol 2012: 948320.

Kovbasnjuk O, Zachos NC, In J, Foulke-Abel J, Ettayebi K, Hyser JM, Broughman JR, Zeng XL, Middendorp S, de Jonge HR, et al. 2013. Human enteroids: Preclinical models of non-inflammatory diarrhea. Stem Cell Res Ther 4: S3.

Krausova M, Korinek V. 2014. Wnt signaling in adult intestinal stem cells and cancer. Cell Signal 26: 570-579.

Lee M, Chang PC, Dunn JC. 2008. Evaluation of small intestinal submucosa as scaffolds for intestinal tissue engineering. J Surg Res 147: 168-171.
Leen JL, Izzo A, Upadhyay C, Rowland KJ, Dube PE, Gu S, Heximer SP, Rhodes CJ, Storm DR, Lund PK, et al. 2011. Mechanism of action of glucagon-like peptide-2 to increase IGF-I mRNA in intestinal subepithelial fibroblasts. Endocrinology 152: 436-446.

Lei NY, Jabaji Z, Wang J, Joshi VS, Brinkley GJ, Khalil H, Wang F, Jaroszewicz A, Pellegrini M, Li L, et al. 2014. Intestinal subepithelial myofibroblasts support the growth of intestinal epithelial stem cells. PLoS ONE 9: e84651.

Levin DE, Barthel ER, Speer AL, Sala FG, Hou X, Torashima Y, Grikscheit TC. 2013. Human tissue-engineered small intestine forms from postnatal progenitor cells. J Pediatr Surg 48: 129-137.

Lim X, Tan SH, Koh WL, Chau RM, Yan KS, Kuo CJ, van Amerongen R, Klein AM, Nusse R. 2013. Interfollicular epidermal stem cells self-renew via autocrine Wnt signaling. Science 342: 1226-1230.

Liu K, Jiang M, Lu Y, Chen H, Sun J, Wu S, Ku WY, Nakagawa H, Kita Y, Natsugoe S, et al. 2013. Sox2 cooperates with inflammation-mediated Stat3 activation in the malignant transformation of foregut basal progenitor cells. Cell Stem Cell 12: 304-315.

Lopez-Garcia C, Klein AM, Simons BD, Winton DJ. 2010. Intestinal stem cell replacement follows a pattern of neutral drift. Science 330: 822-825.

Lundgren O, Jodal M, Jansson M, Ryberg AT, Svensson L. 2011. Intestinal epithelial stem/progenitor cells are controlled by mucosal afferent nerves. PLoS ONE 6: e16295.

Madison BB, Braunstein K, Kuizon E, Portman K, Qiao XT, Gumucio SL. 2005. Epithelial Hedgehog signals pattern the intestinal crypt-villus axis. Development 132: 279289.

Maemura T, Shin M, Kinoshita M, Majima T, Ishihara M, Saitoh D, Ichikura T. 2008. A tissue-engineered stomach shows presence of proton pump and G-cells in a rat model, resulting in improved anemia following total gastrectomy. Artif Organs 32: 234-239.

Maemura T, Shin M, Kinoshita M. 2013. Tissue engineering of the stomach. J Surg Res 183: 285-295.

Matthews JA, Sala FG, Speer AL, Warburton D, Grikscheit TC. 2011. VEGF optimizes the formation of tissue-engineered small intestine. Regen Med 6: 559-567.

McCracken KW, Howell JC, Wells JM, Spence JR. 2011. Generating human intestinal tissue from pluripotent stem cells in vitro. Nat Protoc 6: 1920-1928.

Metzger M, Caldwell C, Barlow AJ, Burns AJ, Thapar N. 2009. Enteric nervous system stem cells derived from human gut mucosa for the treatment of aganglionic gut disorders. Gastroenterology 136: 2214-2225.e1-e3.

Meyerson SL, Mehta CK. 2014. Managing complications II: Conduit failure and conduit airway fistulas. J Thorac Dis 6: S364-S371.

Miki H, Ando N, Ozawa S, Sato M, Hayashi K, Kitajima M. 1999. An artificial esophagus constructed of cultured human esophageal epithelial cells, fibroblasts, polyglycolic acid mesh, and collagen. ASAIO J 45: 502-508.

Mikos AG, Bao Y, Cima LG, Ingber DE, Vacanti JP, Langer R. 1993. Preparation of poly(glycolic acid) bonded fiber structures for cell attachment and transplantation. $J \mathrm{Bi}$ omed Mater Res 27: 183-189. 
Mutter GL. 2001. Pten, a protean tumor suppressor. Am J Pathol 158: 1895-1898.

Nakase Y, Hagiwara A, Nakamura T, Kin S, Nakashima S, Yoshikawa T, Fukuda K, Kuriu Y, Miyagawa K, Sakakura $\mathrm{C}$, et al. 2006. Tissue engineering of small intestinal tissue using collagen sponge scaffolds seeded with smooth muscle cells. Tissue Eng 12: 403-412.

Nakase Y, Nakamura T, Kin S, Nakashima S, Yoshikawa T, Kuriu Y, Miyagawa K, Sakakura C, Otsuji E, Ikada Y, et al. 2007. Endocrine cell and nerve regeneration in autologous in situ tissue-engineered small intestine. J Surg Res 137: $61-68$

Nakase Y, Nakamura T, Kin S, Nakashima S, Yoshikawa T, Kuriu Y, Sakakura C, Yamagishi H, Hamuro J, Ikada Y, et al. 2008. Intrathoracic esophageal replacement by in situ tissue-engineered esophagus. J Thorac Cardiovasc Surg 136: $850-859$

Nakatsu H, Ueno T, Oga A, Nakao M, Nishimura T, Kobayashi S, Oka M. 2013. Influence of mesenchymal stem cells on stomach tissue engineering using small intestinal submucosa. J Tissue Eng Regen Med 9: 296-304.

Nieponice A, Gilbert TW, Johnson SA, Turner NJ, Badylak SF. 2013. Bone marrow-derived cells participate in the long-term remodeling in a mouse model of esophageal reconstruction. J Surg Res 182: e1-e7.

Nieponice A, Ciotola FF, Nachman F, Jobe BA, Hoppo T, Londono R, Badylak S, Badaloni AE. 2014. Patch esophagoplasty: Esophageal reconstruction using biologic scaffolds. Ann Thorac Surg 97: 283-288.

Nillesen ST, Geutjes PJ, Wismans R, Schalkwijk J, Daamen WF, van Kuppevelt TH. 2007. Increased angiogenesis and blood vessel maturation in acellular collagen-heparin scaffolds containing both FGF2 and VEGF. Biomaterials 28: 1123-1131.

Ohki T, Yamato M, Ota M, Takagi R, Murakami D, Kondo M, Sasaki R, Namiki H, Okano T, Yamamoto M. 2012 Prevention of esophageal stricture after endoscopic submucosal dissection using tissue-engineered cell sheets. Gastroenterology 143: 582-588.e1-e2.

Pellegrinet L, Rodilla V, Liu Z, Chen S, Koch U, Espinosa L, Kaestner KH, Kopan R, Lewis J, Radtke F. 2011. Dll1- and dll4-mediated notch signaling are required for homeostasis of intestinal stem cells. Gastroenterology 140: 1230 1240.e1-e7.

Perez A, Grikscheit TC, Blumberg RS, Ashley SW, Vacanti JP, Whang EE. 2002. Tissue-engineered small intestine: Ontogeny of the immune system. Transplantation 74: 619623.

Potten CS, Loeffler M. 1990. Stem cells: Attributes, cycles, spirals, pitfalls and uncertainties. Lessons for and from the crypt. Development 110: 1001-1020.

Que J, Okubo T, Goldenring JR, Nam KT, Kurotani R, Morrisey E, Taranova O, Pevny LH, Hogan BL. 2007. Multiple dose-dependent roles for Sox2 in the patterning and differentiation of anterior foregut endoderm. Development 134: $2521-2531$

Ramalingam S, Daughtridge GW, Johnston MJ, Gracz AD, Magness ST. 2012. Distinct levels of Sox9 expression mark colon epithelial stem cells that form colonoids in culture. Am J Physiol Gastrointest Liver Physiol 302: G10-G20.

Ramsanahie A, Duxbury MS, Grikscheit TC, Perez A, Rhoads DB, Gardner-Thorpe J, Ogilvie J, Ashley SW,
Vacanti JP, Whang EE. 2003. Effect of GLP-2 on mucosal morphology and SGLT1 expression in tissue-engineered neointestine. Am J Physiol Gastrointest Liver Physiol 285: G1345-G1352.

Reynolds A, Wharton N, Parris A, Mitchell E, Sobolewski A, Kam C, Bigwood L, El Hadi A, Munsterberg A, Lewis M, et al. 2014. Canonical Wnt signals combined with suppressed TGF $\beta /$ BMP pathways promote renewal of the native human colonic epithelium. Gut 63: 610-621.

Richardson TP, Peters MC, Ennett AB, Mooney DJ. 2001. Polymeric system for dual growth factor delivery. Nat Biotechnol 19: 1029-1034.

Ritsma L, Ellenbroek SI, Zomer A, Snippert HJ, de Sauvage FJ, Simons BD, Clevers H, van Rheenen J. 2014. Intestinal crypt homeostasis revealed at single-stem-cell level by in vivo live imaging. Nature 507: 362-365.

Roth S, Franken P, Sacchetti A, Kremer A, Anderson K, Sansom O, Fodde R. 2012. Paneth cells in intestinal homeostasis and tissue injury. PLoS ONE 7: e38965.

Rothenberg ME, Nusse Y, Kalisky T, Lee JJ, Dalerba P, Scheeren F, Lobo N, Kulkarni S, Sim S, Qian D, et al. 2012. Identification of a cKit ${ }^{+}$colonic crypt base secretory cell that supports $\mathrm{Lgr}^{+}{ }^{+}$stem cells in mice. Gastroenterology 142: 1195-1205.e6.

Sala FG, Kunisaki SM, Ochoa ER, Vacanti J, Grikscheit TC. 2009. Tissue-engineered small intestine and stomach form from autologous tissue in a preclinical large animal model. J Surg Res 156: 205-212.

Sala FG, Matthews JA, Speer AL, Torashima Y, Barthel ER, Grikscheit TC. 2011. A multicellular approach forms a significant amount of tissue-engineered small intestine in the mouse. Tissue Eng Part A 17: 1841-1850.

Sandle GI. 1998. Salt and water absorption in the human colon: A modern appraisal. Gut 43: 294-299.

Sato M, Ando N, Ozawa S, Nagashima A, Kitajima M. 1993. A hybrid artificial esophagus using cultured human esophageal epithelial cells. ASAIO J 39: M554-M557.

Sato M, Ando N, Ozawa S, Miki H, Kitajima M. 1994. An artificial esophagus consisting of cultured human esophageal epithelial cells, polyglycolic acid mesh, and collagen. ASAIO J 40: M389-392.

Sato T, Vries RG, Snippert HJ, van de Wetering M, Barker N, Stange DE, van Es JH, Abo A, Kujala P, Peters PJ, et al. 2009. Single Lgr5 stem cells build crypt-villus structures in vitro without a mesenchymal niche. Nature 459: 262265.

Sato T, van Es JH, Snippert HJ, Stange DE, Vries RG, van den Born M, Barker N, Shroyer NF, van de Wetering M, Clevers H. 2011. Paneth cells constitute the niche for Lgr5 stem cells in intestinal crypts. Nature 469: 415-418.

Schuijers J, van der Flier LG, van Es J, Clevers H. 2014. Robust cre-mediated recombination in small intestinal stem cells utilizing the olfm4 locus. Stem Cell Rep 3: 234-241.

Schwitalla S, Fingerle AA, Cammareri P, Nebelsiek T, Goktuna SI, Ziegler PL, Canli O, Heijmans J, Huels DJ, Moreaux $\mathrm{G}$, et al. 2013. Intestinal tumorigenesis initiated by dedifferentiation and acquisition of stem-cell-like properties. Cell 152: 25-38.

Scott A, Sullins VF, Steinberger D, Rouch JD, Wagner JP, Chiang E, Lee SL, Wu BM, Dunn JC. 2015. Repeated 
mechanical lengthening of intestinal segments in a novel model. J Pediatr Surg 50: 954-957.

Shyer AE, Huycke TR, Lee C, Mahadevan L, Tabin CJ. 2015. Bending gradients: How the intestinal stem cell gets its home. Cell 161: 569-580.

Sjoqvist S, Jungebluth P, Lim ML, Haag JC, Gustafsson Y, Lemon G, Baiguera S, Burguillos MA, Del Gaudio C, Rodriguez AB, et al. 2014. Experimental orthotopic transplantation of a tissue-engineered oesophagus in rats. Nat Commun 5: 3562.

Snippert HJ, van der Flier LG, Sato T, van Es JH, van den Born M, Kroon-Veenboer C, Barker N, Klein AM, van Rheenen J, Simons BD, et al. 2010. Intestinal crypt homeostasis results from neutral competition between symmetrically dividing Lgr5 stem cells. Cell 143: 134-144.

Speer AL, Sala FG, Matthews JA, Grikscheit TC. 2011. Murine tissue-engineered stomach demonstrates epithelial differentiation. J Surg Res 171: 6-14.

Spence JR, Mayhew CN, Rankin SA, Kuhar MF, Vallance JE, Tolle K, Hoskins EE, Kalinichenko VV, Wells SI, Zorn AM, et al. 2011. Directed differentiation of human pluripotent stem cells into intestinal tissue in vitro. Nature 470: $105-109$.

Spurrier RG, Grikscheit TC. 2013. Tissue engineering the small intestine. Clin Gastroenterol Hepatol 11: 354-358.

Spurrier RG, Speer AL, Grant CN, Levin DE, Grikscheit TC. 2014a. Vitrification preserves murine and human donor cells for generation of tissue-engineered intestine. J Surg Res 190: 399-406.

Spurrier RG, Speer AL, Hou X, El-Nachef WN, Grikscheit TC. 2014b. Murine and human tissue-engineered esophagus form from sufficient stem/progenitor cells and do not require microdesigned biomaterials. Tissue Eng Part A 21: 906-915.

Stange DE, Koo BK, Huch M, Sibbel G, Basak O, Lyubimova A, Kujala P, Bartfeld S, Koster J, Geahlen JH, et al. 2013. Differentiated Troy ${ }^{+}$chief cells act as reserve stem cells to generate all lineages of the stomach epithelium. Cell 155: 357-368.

Tan B, Wang M, Chen X, Hou J, Chen X, Wang Y, Li-Ling J, Xie H. 2014. Tissue engineered esophagus by copperSmall intestinal submucosa graft for esophageal repair in a canine model. Sci China Life Sci 57: 248-255.

Torashima Y, Levin DE, Barthel ER, Speer AL, Sala FG, Hou X, Grikscheit TC. 2013. Fgf10 overexpression enhances the formation of tissue-engineered small intestine. J Tissue Eng Regen Med 10: 132-139.

Vacanti JP, Morse MA, Saltzman WM, Domb AJ, PerezAtayde A, Langer R. 1988. Selective cell transplantation using bioabsorbable artificial polymers as matrices. $J \mathrm{Pe}$ diatr Surg 23: 3-9.

van den Brink GR, Bleuming SA, Hardwick JC, Schepman BL, Offerhaus GJ, Keller JJ, Nielsen C, Gaffield W, van Deventer SJ, Roberts DJ, et al. 2004. Indian Hedgehog is an antagonist of Wnt signaling in colonic epithelial cell differentiation. Nat Genet 36: 277-282. van der Flier LG, van Gijn ME, Hatzis P, Kujala P, Haegebarth A, Stange DE, Begthel H, van den Born M, Guryev V, Oving I, et al. 2009. Transcription factor achaete scutelike 2 controls intestinal stem cell fate. Cell 136: 903-912.

van de Wetering M, Sancho E, Verweij C, de Lau W, Oving I, Hurlstone A, van der Horn K, Batlle E, Coudreuse D, Haramis AP, et al. 2002. The $\beta$-catenin/TCF- 4 complex imposes a crypt progenitor phenotype on colorectal cancer cells. Cell 111: 241-250.

van Es JH, Sato T, van de Wetering M, Lyubimova A, Nee AN, Gregorieff A, Sasaki N, Zeinstra L, van den Born M, Korving J, et al. 2012. Dll1 ${ }^{+}$secretory progenitor cells revert to stem cells upon crypt damage. Nat Cell Biol 14: 1099-1104.

Van Landeghem L, Santoro MA, Krebs AE, Mah AT, Dehmer JJ, Gracz AD, Scull BP, McNaughton K, Magness ST, Lund PK. 2012. Activation of two distinct Sox9-EGFP-expressing intestinal stem cell populations during crypt regeneration after irradiation. Am J Physiol Gastrointest Liver Physiol 302: G1111-G1132.

Van Landeghem L, Santoro MA, Mah AT, Krebs AE, Dehmer JJ, McNaughton KK, Helmrath MA, Magness ST, Lund PK. 2015. IGF1 stimulates crypt expansion via differential activation of 2 intestinal stem cell populations. FASEB J 29: 2828-2842.

Wales PW, de Silva N, Kim JH, Lecce L, Sandhu A, Moore AM. 2005. Neonatal short bowel syndrome: A cohort study. J Pediatr Surg 40: 755-762.

Walther V, Graham TA. 2014. Location, location, location! The reality of life for an intestinal stem cell in the crypt. J Pathol 234: 1-4.

Walthers CM, Lee M, Wu BM, Dunn JC. 2014. Smooth muscle strips for intestinal tissue engineering. PLoS ONE 9: e114850.

Watson CL, Mahe MM, Munera J, Howell JC, Sundaram N, Poling HM, Schweitzer JI, Vallance JE, Mayhew CN, Sun Y, et al. 2014. An in vivo model of human small intestine using pluripotent stem cells. Nat Med 20: 1310-1314.

Watt FM, Hogan BL. 2000. Out of Eden: Stem cells and their niches. Science 287: 1427-1430.

Wilson SS, Tocchi A, Holly MK, Parks WC, Smith JC. 2014. A small intestinal organoid model of non-invasive enteric pathogen-epithelial cell interactions. Mucosal Immunol 8: $352-361$.

Yui S, Nakamura T, Sato T, Nemoto Y, Mizutani T, Zheng X, Ichinose S, Nagaishi T, Okamoto R, Tsuchiya K, et al. 2012. Functional engraftment of colon epithelium expanded in vitro from a single adult $\mathrm{Lgr}^{+}{ }^{+}$stem cell. Nat Med 18: 618-623.

Zimmerman ZF, Moon RT, Chien AJ. 2012. Targeting Wnt pathways in disease. Cold Spring Harb Perspect Biol 4: a008086.

Zucoloto S, de Deus DA, Martins AA, Muglia VF, Kajiwara JK, Garcia SB. 1997. The relationship between myenteric neuronal denervation, smooth muscle thickening and epithelial cell proliferation in the rat colon. Res Exp Med (Berl) 197: 117-124. 


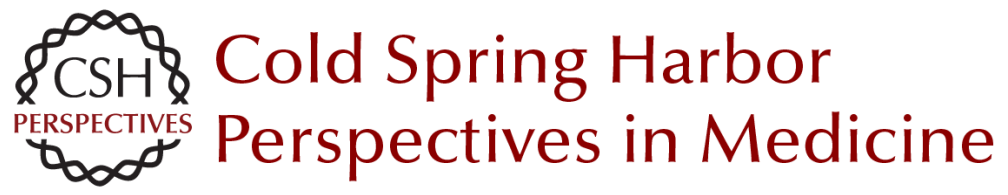

\title{
Tissue Engineering Functional Gastrointestinal Regions: The Importance of Stem and Progenitor Cells
}

\author{
Andrew Trecartin and Tracy Grikscheit
}

Cold Spring Harb Perspect Med 2017; doi: 10.1101/cshperspect.a025700 originally published online March 20, 2017

\section{Subject Collection Tissue Engineering and Regenerative Medicine}

The Heart and Great Vessels

Ekene Onwuka, Nakesha King, Eric Heuer, et al.

Three-Dimensional Bioprinting Strategies for Tissue Engineering

Yu Shrike Zhang, Rahmi Oklu, Mehmet Remzi

Dokmeci, et al.

Honing Cell and Tissue Culture Conditions for Bone and Cartilage Tissue Engineering

Johnny Lam, Esther J. Lee, Elisa C. Clark, et al.

Tissue Engineering Functional Gastrointestinal Regions: The Importance of Stem and Progenitor Cells

Andrew Trecartin and Tracy Grikscheit

\author{
Historical Perspective and Future Direction of \\ Blood Vessel Developments \\ Sashka Dimitrievska and Laura E. Niklason \\ Craniofacial Tissue Engineering \\ Weibo Zhang and Pamela Crotty Yelick
}

The Self-Assembling Process and Applications in Tissue Engineering

Jennifer K. Lee, Jarrett M. Link, Jerry C.Y. Hu, et al.

Biologic Scaffolds

Alessandra Costa, Juan Diego Naranjo, Ricardo Londono, et al.

For additional articles in this collection, see http://perspectivesinmedicine.cshlp.org/cgi/collection/ 